\title{
MENILIK ASPEK MORAL DALAM LIRIK LAGU CAMPURSARI JAWA TIMUR: SEBUAH KAJIAN SEMIOTIKA
}

\author{
Afry Adi Chandra \\ SMK Negeri 1 Udanawu, Udanawu, Blitar, Jawa Timur \\ afryadichandra@yahoo.com
}

\begin{abstract}
This qualitative research approach with semiotics approach proposed by Ferdinand D. Saussure aims to find out the crisis of morality that found in the lyrics of Campursari songs composed by East Javanese musicians. The findings show that the advancement of technology is the development of people's ways of thinking and currently there are many Campursari songs produced by several local East Javanese artists lacking of morality. The works emphasize on sexuality, attitude fighting against norms in society (fraud), polygamy, unemployment, scandals unfolding, and prestige humiliation.
\end{abstract}

Keywords: morality, the song lyrics of campursari, East Java, semiotics

\begin{abstract}
ABSTRAK
Penelitian kualitatif dengan pendekatan semiotika(Ferdinand D. Saussure) ini bertujuan untuk meninjau aspek moral yang terdapat dalam lirik lagu campursari karya musisi Jawa Timur. Temuan penelitian menunjukkan bahwa dengan semakin berkembangnya teknologi pun cara berpikir masyarakat, saat ini banyak bermunculan lagu campursari karya beberapa seniman lokal Jawa Timur yang krisis akan moral. Karya tersebut lebih mengangkat sisi seksualitas, sikap melawan tataran norma dalam masyarakat (perselingkuhan), poligami, pengangguran, membuka aib seseorang, maupun merendahkan martabat orang lain.
\end{abstract}

Kata kunci: moral, lirik lagu campursari, Jawa Timur, semiotika

\section{PENGANTAR}

Seiring perkembangan zaman, karya seni semakin bervariasi jenisnya. Salah satu wujud karya seni yang akrab dengan kehidupan sehari-hari manusia adalah seni musik. Musik adalah suatu hasil karya seni bunyi dalam bentuk lagu atau komposisi musik yang mengungkapkan pikiran dan perasaan penciptanya melalui unsur-unsur musik, yaitu irama, melodi, harmoni, bentuk, dan struktur lagu dan ekpresi sebagai satu kesatuan (Jamalus, 1988:1). Sebagai sarana ekpresi, musik juga berkembang dengan pesat, terutama di era digitalisasi saat ini. Dalam perkembangannya, musik di Indonesia tumbuh dalam beragam aliran/genre. 
Aliran-aliran tersebut muncul sebagai wujud kreativitas para pegiatnya maupun akibat dari permintaan pasar. Begitu pula masyarakat Jawa, dunia kesenian tumbuh sesuai dengan karakter khas dari masyarakatnya. Dalam khasanah masyarakat Jawa, gamelan memiliki peran yang amat penting dalam menhidupkan kesenian Jawa. Perpaduan antara gamelan dengan musik modern yang kemudian memuncukan produk baru, yaitu musik campursari. Menurut Krisnada (2014), musik campursari adalah sejenis orkes keroncong dengan alat musik di padukan dengan alat musik gamelan dan alat musik dangdut (elektrik). Campursari menyebar di daerah Jawa Tengah, Yogyakarta, serta sebagian Jawa Timur. Pengembangan dari musik langgam Jawa ini pertama kali diperkenalkan sekitar tahuan 1980-an oleh Manthous dengan memasukkan unsur keyboard ke dalam permainan gamelan. Pada masa itu, kelompok gamelan yang dipergunakan sebagai sarana penyampaian kreativitasnya adalah "Maju Lancar". Eksperimen awal yang dilakukan Manthous di Gunung Kidul ini sebenarnya hanya memasukkan unsur keyboard dalam permainan musiknya. Akan tetapi, seiring berjalannya waktu unsur musik lain juga ikut masuk, yaitu keroncong pun dangdut. Hal inilah yang membuat musik campursari makin berkembang dan diminati masyarakat.

Sebagai sebuah karya seni, selain memiliki fungsi untuk menghibur, musik campursari juga membawa misi untuk menyampaikan ajaran moral kepada para penikmatnya. Wujud ajaran moral tersebut seperti, menghormati orang tua, menjaga hubungan baik dengan lingkungan sekitar, rendah hati, mengucap syukur atas karunia Tuhan, serta ajakan menuju kebaikan lainnya. Hampir sama dengan aliran musik lain, ada berbagai fungsi yang di dapat dari musik campursari. Ada dua macam fungsi yaitu primer meliputi; (1) sebagai sarana ritual, (2) sarana hiburan pribadi, dan (3) sebagai prosentasi estetis. Adapun untuk fungsi sekunder terdapat sembilan fungsi, yaitu; (1) sebagai pengikat solidaritas kelompok, (2) sebagai pembangkit rasa solidaritas bangsa, (3) sebagai media komunikasi bangsa, (4) sebagai media propaganda keagamaan, (5) sebagai media propaganda politik, (6) sebagai media propaganda programprogram pemerintah, (7) sebagai media meditasi, (8) sebagai sarana terapi, dan (9) sebagai perangsang produktivitas (Soedarsono, 1999:167169). Berdasarkan pemaparan tersebut diperoleh informasi bahwa musik campursari memiliki manfaat yang cukup banyak bagi kehidupan masyarakat Jawa utamanya.

Jawa Timur sebagai bagian dari masyarakat Jawa juga memiliki karakter tersendiri dalam karyakarya musik campursari. Kondisi lingkungan masyarakat, minat pasar musik campursari, maupun psikologi penikmatnya menjadi beberapa faktor yang dapat menentukan kekhasan produk musik campursari kreasi para musisi Jawa Timur. Nur Bayan, Edy Sonata, dan Rony Jembuk merupakan beberapa musisi campursari dari Jawa Timur yang aktif meramaikan 
industri musik campursari. Seiring perkembangan pasar, musik campursari juga terus berinovasi mengikuti permintaan masyarakat. Apalagi saat ini, industri musik dangdut juga tumbuh subur di daerah Jawa Timur. Fenomena tersebut juga berdampak pada naiknya minat musik campursari di tengahtengah masyarakat. Pada praktiknya, musik campursari juga semakin sering ditampilkan pada hajatan dangdut maupun pementasan wayang kulit di daerah Jawa Timur.

Selain sebagai pemberi pesan moral dalam perkembangannya, cukup banyak musik campursari karya musisi Jawa Timur yang justru mengarah terhadap sikap krisis moral atau degradasi moral. Menurut Azizah (2016), degradasi moral merupakan suatu fenomena adanya kemerosotan atas budi pekerti seseorang maupun sekelompok orang. Apabila dirunut, kemunculan karyakarya campursari yang krisis akan moral tersebut disebabkan karena faktor ekonomi (mencari keuntungan sebanyak-banyaknya). Ditambah lagi dengan sikap masyarakat yang 'menerima' saja produk tersebut dengan tanpa merasa risau, membuat karya krisis moral ini semakin tumbuh subur. Tema seksualitas, perselingkuhan, poligami, maupun merendahkan orang lain menjadi semakin terbiasa terdengar di telinga masyarakat, berkat kemunculannya yang cukup intens hasil dari produk music campursari. Nilai-nilai krisis moral seperti ini harus dijauhkan dari telinga generasi masa depan. Hal ini dapat memberikan dampak yang luar biasa terhadap psikologi tumbuh kembang mereka.
Penelitian deskriptif interpretatif ini bertujuan untuk mengetahui krisis moral yang terdapat dalam lirik lagu campursari karya musisi Jawa Timur. Pendekatan yang dipergunakan adalah pendekatan semiotika (teori Ferdinand D. Sausure). Menurut de Saussure, setiap kata merupakan tanda (sign); dan setiap tanda selalu terdiri atas penanda (signifier) dan petanda (signified) (Kadarisman, 2008:2). Melalui pendekatan ini, bahasa dapat dikaji dengan menggunakan fungsi penanda (signifier) dan petanda (signified). Pada akhirnya, penelitian ini dapat memberikan informasi terkait krisis moral dalam lirik lagu campursari karya musisi Jawa Timur yang memiliki dampak buruk bagi perkembangan generasi muda masa depan.

\section{TEORI DAN METODE PENELITIAN}

Penelitian deskriptif kualitatif merupakan jenis penelitian yang dipergunakan dalam kajian ini. Penelitian kualitatif adalah penelitian yang bermaksud untuk memahami fenomena tentang apa yang dialami oleh subjek penelitian misalnya, perilaku, persepsi, motivasi, tindakan, dan lain-lain secara holistik dan dengan cara deskripsi dalam bentuk katakata dan bahasa, pada suatu konteks khusus yang alamiah dan dengan memanfaatkan berbagai metode alamiah (Moleong, 2005:6). Pendekatan yang dipergunakan merupakan pendekatan semiotika Ferdinand $D$. Sausurre. Menurut Ferdinand, bahasa sebagai sebuah sistem tanda terdiri atas penanda (signifier) dan petanda (signified). 
Pengumpulan data pada dasarnya merupakan serangkaian proses yang dilakukan sesuai dengan metode penelitian yang dipergunakan (Suharsaputra, 2012:207). Sumber data dalam penelitian ini adalah lirik lagu campursari karya musisi Jawa Timur yang mengandung unsur krisis moral didalamnya. Penentuan muatan kriris moral tersebut didasarkan pada pengamatan serta analisis isi lirik lagu campursari. Penentuan sampel penelitian didasarkan pada model purposive sampling. Penentuan sampel lirik lagu yang dianalisis dengan menggunakan pendekatan semiotika Ferdinand D. Saussure didasarkan pada aspek (1) keterwakilan tema tertentu yang mencerminkan muatan krisis moral dalam lirik lagu campursari, (2) karya lagu campursari merupakan buatan musisi Jawa Timur, serta (3)karya lagu campursari lebih mengedepankan aspek hiburan semata, tanpa memperhatikan unsur pendidikan. Maka, lirik lagu yang dianalisis dalam penelitian ini meliputi lagu berjudul Bojo Ketelu karya Nur Bayan mewakili tema poligami, Kebelet karya Edy Sonata mewakili tema seksualitas, serta Aja Njaluk Pegat karya Rony Jembuk sebagai salah satu contoh tema percekcokan rumah tangga.

Pengumpulan data dapat dilakukan dalam berbagai setting, berbagai sumber, dan berbagai cara (Sugiyono, 2016:308). Teknik pengumpulan data dalam penelitian ini adalah dengan memahami isi lirik lagu campursari karya musisi Jawa Timur dengan memperhatikan aspek penanda (signifier) dan petanda (siginified), seperti, lirik campursari Bojo Ketelu karya Nur Bayan, Kebelet karya Edy Sonata, serta Ojo Njaluk Pegat karya Rony Jembuk. MenurutSugiyono(2016), analisis data adalah proses mencari dan menyusun secara sistematis data yang diperoleh dari hasil wawancara, catatan lapangan, dan dokumentasi, dengan cara mengorganisasikan data ke dalam kategori, menjabarkan ke dalam unit-unit, melakukan sintesa, menyusun ke dalam pola, memilih mana yang penting dan yang akan dipelajari, dan membuat kesimpulan sehingga mudah dipahami oleh diri sendiri maupun orang lain. Analisis data dalam penelitian ini mengacu pada teori semiotika Ferdinand D. Saussure, bahwa aspek penanda dan petanda harus diperhatikan dalam aktivitas analisis, seperti lirik lagu campursari. Sasussure meletakkan tanda dalam konteks komunikasi manusia dengan melakukan pemilahan antara apa yang disebut signifier (penanda)dan signified (petanda) (Suparapto, 2009: 103). Analisis data diawali dengan memahami keseluruhan lirik lagu campursari yang dijadikan sebagai sampel. Memahami isi cerita yang terdapat didalam lirik lagu campursari juga menjadi bagian penting sebelum mengkajinya secara lebih komprehensif. Langkah kedua adalah membagi lirik lagu menjadi beberapa bagian bait, langkah ini bertujuan untuk memudahkan analisis agar menemukan fokus dalam pengkajiannya. Berikutnya, menafsirkan aspek penanda (signifier) serta petanda (signified) yang ada dalam tiap bait lirik lagu campursari tersebut. Keempat membuat konklusi antara 
temuan tanda-tanda yang ada dengan situasi sosial budaya masyarakat penikmat musik campursari tersebut. Melalui beberapa tahapan tersebut, akan memudahkan peneliti dalam melakukan analisis data penelitian dengan jelas.

\section{HASIL DAN PEMBAHASAN}

Berdasarkan penelitian yang telah dilakukan, didapatkan hasil terkait aspek krisis moral dalam lirik lagu campursari. Wujud krisis moral tersebut cukup beragam. Adapun pemaparan hasil serta pembahasannya dipaparkan sebagai berikut.

\section{Krisis Moral Lirik Lagu Campursari Daerah Jawa Timur}

Tujuan utama dari penciptaan musik campursari adalah sebagai sarana hiburan. Implementasi hiburan tersebut tergambar dalam alunan kombinasi alat musik gamelan dengan alat musik modern. Dari perpaduan tersebut, muncullah aliran musik bernama campursari. Fungsi ekspresi diri juga dapat menjadi pendorong terciptanya sebuah ide tentang isi dari sebuah lagu campursari. Penelitian ini lebih berfokus pada musik campursari sebagai sarana pendidikan moral terhadap masyarakat. Moral adalah suatu keyakinan tentang benar salah, baik dan buruk, yang sesuai dengan kesepakatan sosial, yang mendasari tindakan atau pemikiran (Ibung, 2009:3). Pendidikan moral menjadi kebutuhan penting bagi perkembangan generasi masa depan. Misi tersebut juga dapat dilaksanakan dengan memanfaatkan muatan moral dalam lirik lagu campursari. Sebagai sebuah produk kearifan lokal, khususnya masyarakat Jawa, campursari menjadi salah satu sarana pendidikan moral bagi masyarakat. Selain sebagai sarana pendidikan moral, campursari juga sebagai sarana pelestari kebudayaan, respon sosial, ekonomi (keuntungan), serta motif lainnya.

Seiring perkembangan zaman, campursari juga terus menyesuaikan diri. Dari segi tema yang diangkat juga semakin bervariasi. Berbagai aspek kehidupan menjadi inspirasi penciptaan lirik lagu campursari. Tema tentang asmara, semangat kerja, sikap syukur, keagungan Tuhan, hingga hidup bermasyarakat banyak diangkat dalam bentuk lagu-lagu campursari. Dengan bergulirnya zaman, ternyata tema-tema yang diangkat tak hanya tentang sikap positif saja. Bahkan belakangan, banyak juga tema-tema tak mendidik diangkat, seperti tema tentang perceraian, pertengkaran, perselingkuhan, serta seksualitas. Tema tersebut menjadi cukup sering diangkat dalam bentuk lagu campursari.

Berikut dibahas beberapa lirik lagu campursari daerah Jawa Timur yang tidak memiliki muatan pendidikan/ sikap moral positif. Pemilihan lirik lagu dibawah ini dilakukan berdasarkan aspek isi lagu terhadap tema (krisis moral) tertentu. Bentuk krisis moral tersebut bisa saja dalam bentuk gambaran perselingkuhan, menampilkan sisi seksualitas, serta perceraian (mengumbar aib). Tematema tersebut mewakili sisi krisis moral yang ada dalam lirik lagu campursari 
yang telah beredar di masyarakat, utamanya daerah Jawa Timur. Penelitian initidakbermaksud untuk merendahkan si penulis lagu campursari, tetapi lebih menyoroti terhadap konten lirik lagu yang disampaikan.

Nur Bayan, salah satu seniman campursari asal Kediri (Jawa Timur) ini cukup aktif dalam membuat karya. Pria kelahiran Kediri, 14 Juni 1983, ini sudah memulai pergelutan dengan dunia music sejak tahun 1990-an. Pada tahun 2013-an, sosok Nur Bayan semakin dikenal masyarakat luas. Hal ini berkat lagu ciptaannya yang berjudul Oplosan, yang acapkali dibawakan di depan "layar kaca". Berkat lagu andalannya tersebut, nama Nur Bayan semakin "tenar" hingga sekarang. Peran Nur Bayan dalam jagat industri musik campursari tidak diragukan lagi, utamanya di daerah Jawa Timur. Beragam tema kehidupan dia sangat paham bentuk lagu campursari, mulai dari cinta hingga refleksi tentang kehidupan yang dia curahkan. Dibalik misi membawa ajaran moral bagi kehidupan masyarkat, ternyata ada beberapa karya musik campursari ciptaan Nur Bayan yang mengandung unsur kriris moral didalamnya. Moral sangat berkontribusi penting bagi pembentukan karakter manusia. Kebaikan selalu identik dengan moral. Orang yang tidak baik juga disebut sebagai orang yang tidak bermoral, atau sekurang-kurangnya sebagai orang yang kurang bermoral (Hadiwardoyo, 1994:13). Lagu-lagu yang krisis moral tersebut kebanyakan hanya menguak sisi negatif, misalnya lagu berjudul Bojo Ketelu ciptaan Nur Bayan. Lagu ini bercerita tentang curahan hati seorang perempuan yang ingin diakui secara resmi kisah cintanya dengan seorang laki-laki. Padahal, sang lelaki sudah beristri dua (berpoligami). Lagu tersebut disampaikan dalam bentuk bahasa daerah (bahasa Jawa). Bahasa daerah, yaitu bahasa ibu atau bahasa pertama bagi sebagaian besar rakyat Indonesia, adalah bahasa yang dapat digunakan dalam interaksi baik dalam situasi resmi maupun tidak yang bersifat kedaerahan (Chaer dan Agustina, 2004:212). Berikut analisis lirik lagu Bojo Ketelu ciptaan Nur Bayan dengan menggunakan aspek penanda (signifier) serta petanda (signified).

Tabel 1. Analisis bait pertama lirik lagu Bojo Ketelu ciptaan Nur Bayan

\begin{tabular}{|c|c|}
\hline Aspek Penanda (Signifier) & Aspek Petanda (Signified) \\
\hline $\begin{array}{l}\text { Aku kepingin dadi kelip kelip lintang. } \\
\text { Aku ingin menjadi kerlap-kerlip bintang } \\
\text { Sing bisa ngancani ing sak ben wengimu. } \\
\text { Yang bisa menemani setiap malammu } \\
\\
\text { Nanging aku sadar aku mung lampune lilin. } \\
\text { Tetapi aku sadar, aku hanya cahaya lilin. }\end{array}$ & $\begin{array}{l}\text { Lagu ini bercerita tentang curahan } \\
\text { hati seorang perempuan yang menjadi } \\
\text { "istri simpanan". Dalam etika masyarakat, } \\
\text { menjadi istri simpanan merupakan } \\
\text { perbuatan yang tabu atau tidak pantas } \\
\text { untuk dilakukan. Dalam lirik lagu ini, sang } \\
\text { pencipta menggambarkan si perempuan }\end{array}$ \\
\hline
\end{tabular}




\begin{tabular}{|l|l|}
\hline \multicolumn{1}{|c|}{ Aspek Penanda (Signifier) } & \multicolumn{1}{c|}{ Aspek Petanda (Signified) } \\
\hline $\begin{array}{l}\text { Sing mobat-mabit kena silire angin. } \\
\text { Yang terombang-ambing terkena } \\
\text { semilir angin. }\end{array}$ & $\begin{array}{l}\text { (istri simpanan) merasa tidak ikhlas/rela } \\
\text { menjadi istri simpanan. Akan tetapi, karena } \\
\text { keadaan dan cinta yang telah membara, hal } \\
\text { ini membuat "si istri simpanan" mencoba } \\
\text { untukikhlas. Padahal, ia amat mendambakan } \\
\text { hidup bahagia bersama dengan si suami. }\end{array}$ \\
$\begin{array}{l}\text { Umpoma sliramu ngerti rasa atiku iki. } \\
\text { Seumpama dirimu tahu perasaan ini. } \\
\begin{array}{l}\text { Kaya ngapa larane dadi bojo simpenan. } \\
\text { Seperti apa sakitnya menjadi istri simpanan. }\end{array}\end{array}$ \\
$\begin{array}{l}\text { Tenane aku nangis kaya-kaya ra lila. } \\
\text { Sebenarnya aku menangis tidak rela. } \\
\begin{array}{l}\text { Nanging kepriye maneh aku kebacut tresna. } \\
\text { Akan tetapi, mau bagaimana lagi, aku } \\
\text { terlanjur cinta. }\end{array}\end{array}$ \\
\hline
\end{tabular}

Fenomena poligami bukan hal baru bagi masyarakat di sekitar kita. Melihat fenomena tersebut yang semakin berkembang cepat, pemerintah telah membuat aturan yang makin mempersempit "ruang gerak" dari tindakan poligami ini. Hal ini dilakukan karena tindakan poligami acapakali justru menimbulkan masalah baru yang kompleks, utamanya yang berkaitan dengan masalah sosial. Fenomena tersebut begitu tampak dalam lirik lagu Bojo Ketelu ciptaan Nur Bayan di atas. Lagu sebagai salah satu produk sebuah kebudayaan, amat disayangkan apabila didalamnya memuat sikap yang mencerminkan perilaku kurang terpuji. Melalui media bahasa, isi lagu yang disampaikan para musisi dapat ditangkap oleh khalayak umum. Kebudayaan suatu bangsa tidaklah mungkin dapat dikaji tanpa mengkaji bahasa bangsa itu, karena bahasa bangsa itu (penduduk asli) adalah bagian dari kebudayaan bangsa itu (Chaer, 2003:62).

Saat ini cukup banyak fenomena poligami dalam kehidupan masyarakat. Poligamiadalah sistem perkawinan yang salah satu pihak memiliki/mengawini beberapa lawan jenisnya dalam waktu yang bersamaan (Mulia et al, 2007:2). Ada beragam motif seseorang mau "dimadu". Motif ekonomi menjadi hal yang paling dominan terjadi. Ekonomi yang sulit terkadang membuat seorang perempuan mengambil "jalan pintas", agar kehidupannya jauh lebih baik. Sementara itu, ada berbagai motif yang melatarbelakangi seorang laki-laki melakukan tindakan poligami. Akan tetapi, faktor pemenuhan kebutuhan biologis lah yang paling dominan melatarbelakangi seorang laki-laki melakukan poligami. Hal tersebut dapat ditangkap melalui analisis dalam tabel di bawah ini. 
Tabel 2. Analisis bait pertama lirik lagu Bojo Ketelu ciptaan Nur Bayan

\begin{tabular}{|c|c|}
\hline Aspek Penanda (Signifier) & Aspek Petanda (Signified) \\
\hline $\begin{array}{l}\text { Wis aja nelangsa, wis aja ngersula. } \\
\text { Sudahlah jangan merana, jangan mengeluh. } \\
\text { Donga-dongana bojoku lila. } \\
\text { Doakan istriku ikhlas. } \\
\text { Wis aja nelangsa, wis aja ngersula. } \\
\text { Sudahlah jangan merana, jangan mengeluh. } \\
\text { Dungak-dungakno bojoku lila. } \\
\text { Doakan ustriku ikhlas. } \\
\text { Nrima awakmu dadi bojoku, } \\
\text { Menerima dirimu menjadi istriku. } \\
\text { Senadyan bojo ketelu. } \\
\text { Meskipun jadi istri ketiga. }\end{array}$ & $\begin{array}{l}\text { Pada bait kedua, si suami mencoba } \\
\text { menguatkan "si istri simpanan" untuk tidak } \\
\text { merana serta mengeluh. Ia meminta si istri } \\
\text { simpanan untuk berdoa, semoga istri dari } \\
\text { sang suami bisa ikhlas menerima dia (istri } \\
\text { simpanan) untuk hidup bersama. Keinginan } \\
\text { hidup bersama dalam satu rumah sudah } \\
\text { menjadi impian keduanya ("istri simpanan" } \\
\text { dengan sang suami). Meskipun, ternyata } \\
\text { "si istri simpanan" ini akan dijadikan istri } \\
\text { ketiganya (poligami). Namun, keadaan saat } \\
\text { ini belum memungkinkan untuk terwujud. } \\
\text { Ada beberapa kendala yang menghalangi } \\
\text { impian keduanya. }\end{array}$ \\
\hline $\begin{array}{l}\text { Selain, tema tentang "poligami", ada } \\
\text { tema lain terkait krisis moral dalam lirik } \\
\text { lagu campursari karya musisi daerah } \\
\text { Jawa Timur, yaitu tema seksualitas. } \\
\text { Seksualitas adalah kebutuhan dasar } \\
\text { manusia dalam manifestasi kehidupan } \\
\text { yang berhubungan dengan alat } \\
\text { reproduksi (Stevens et al., 1992:275). } \\
\text { Sebenarnya, seksualitas bukan } \\
\text { perkara tabu untuk dibahas, tetapi } \\
\text { bila salah dalam "mewujudkannya" } \\
\text { dapat menimbulkan hal-hal negatif, }\end{array}$ & $\begin{array}{l}\text { tua harus menjaga, supaya dalam } \\
\text { pendidikan mereka seksualitas jangan } \\
\text { diisolir, tetapi mendapat tempatnya } \\
\text { dalam keseluruhan kepribadian si } \\
\text { anak (Abineno, 2002:35). Saat ini, } \\
\text { cukup banyak lagu campursari yang } \\
\text { mengandung unsur seksualitas di } \\
\text { dalam liriknya. Berikut ini merupakan } \\
\text { contoh lirik lagu karya Edy Sonata yang } \\
\text { berjudul Kebelet. Analisis lebih lanjut } \\
\text { terkait lirik lagu campursari berjudul } \\
\text { Kebelet ciptaan Edy Sonata adalah } \\
\text { sehagai herikut }\end{array}$ \\
\hline
\end{tabular}

Karena itu, mereka sebagai orang

Tabel 3. Analisis bait pertama lirik lagu Kebelet

ciptaan Edy Sonata

\begin{tabular}{|l|l|}
\hline \multicolumn{1}{|c|}{ Aspek Penanda (Signifier) } & \multicolumn{1}{c|}{ Aspek Petanda (Signified) } \\
\hline $\begin{array}{l}\text { Dik, awakmu mrenea. } \\
\text { Dik, kamu kesinilah. }\end{array}$ & $\begin{array}{l}\text { Pada bait pertama lagu ini berkisah } \\
\text { tentang seorang suami yang memanggil } \\
\text { sang istri. Mendengar panggilan sang suami, } \\
\text { si istri pun mendekat. Suami tersebut } \\
\text { membisikkan sesuatu secara perlahan agar } \\
\text { Medak'o aja adoh-adoh. } \\
\text { tak terdengar tetangga ke telinga si istri. Isi } \\
\text { bisikan tersebut ternyata, sang suami yang }\end{array}$ \\
$\begin{array}{l}\text { Mepeta tak bisiki lirih-lirih. } \\
\text { Merapatlah, aku bisiki pelan-pelan. }\end{array}$ & \\
\hline
\end{tabular}




\begin{tabular}{|l|l|}
\hline \multicolumn{1}{|c|}{ Aspek Penanda (Signifier) } & \multicolumn{1}{c|}{ Aspek Petanda (Signified) } \\
\hline $\begin{array}{l}\text { Cekgak kerungu tangga kanan-kiri. } \\
\text { Biar tidak terdengar tetangga kanan-kiri. }\end{array}$ & $\begin{array}{l}\text { sedang merasa "nafsu". Nanti malam sang } \\
\text { suami meminta jatah hubungan suami istri } \\
\text { kepada sang istri. Tulang dan otot yang kaku } \\
\text { menjadi alasan sang suami melontarkan } \\
\text { permintaan tersebut. Alasan semakin } \\
\text { dibuat-buat sang suami untuk merayu si } \\
\text { Dik, aku sudah nafsu. }\end{array}$ \\
$\begin{array}{l}\text { Engko bengi aku njaluk iku. } \\
\text { Nanti malam aku minta "itu". } \\
\text { yang telah memuncak tersebut tidak } \\
\text { terlayani dengan baik. }\end{array}$ \\
$\begin{array}{l}\text { Balung karo ototku pada kaku. } \\
\text { Tulang dan otoku sudah kaku. }\end{array}$ \\
$\begin{array}{l}\text { Lekgak ngana, ora isa turu. } \\
\text { Kalau tidak begitu, aku tak bisa tidur. }\end{array}$ \\
\hline
\end{tabular}

Seks merupakan kebutuhan setiap manusia yang telah memasuki masa dewasa. Sebagai suatu fenomena biologis, aktivitas seksual harus disesuaikan dan dikendalikan melalui norma dan aturan yang berlaku pada suatu kelompok masyarakat. Bagi bangsa Indonesia, aktivitas ini harus dilakukan dalam ikatan pernikahan. Aturan ini bertujuan agar aktivitas seksual tidak menyalahi aturan, baik dari segi budaya maupun agama.
Sebagai ranah pribadi, harusnya akivitas yang berkaitan dengan seksual tidak dipublikasi ataupun disebarluaskan kepada khalayak luas. Hal ini amat berbahaya apabila anak-anak di bawah umur juga turut mengkonsumsinya. Tidak disangkal bahwa di dalam seksualitas terdapat kemampuan yang merusak, yang dapat membuat manusia kehilangan kemanusiaannya (Widyarini, 2009:71).

Tabel 4. Analisis bait kedua lirik lagu Kebelet ciptaan Edy Sonata

\begin{tabular}{|l|l|}
\hline \multicolumn{1}{|c|}{ Aspek Penanda (Signifier) } & \multicolumn{1}{c|}{ Aspek Petanda (Signified) } \\
\hline $\begin{array}{l}\text { Cak, omongku rungokna. } \\
\text { Mas, dengarkan omonganku. }\end{array}$ & $\begin{array}{l}\text { Sang istri menjawab permintaan suami } \\
\text { pada bait kedua lirik lagu Kebelet ini. Ia } \\
\text { menceritakan apa adanya kepada sang suami. } \\
\text { Tahwa pada saat ini ia sedang kedatangan } \\
\text { Aku kasih cerita tentang perkara ini. }\end{array}$ \\
$\begin{array}{l}\text { "tamu bulanan"/haid. Dalam dunia kesehatan } \\
\text { terdapat larangan, ketika perempuan sedang } \\
\text { Sawahmu durung kenek dipaculi. } \\
\text { haid, ia tidak boleh melakukan hubungan } \\
\text { seksual dengan suaminya. Hal ini dikarenakan } \\
\text { dapat berdampak buruk bagi si perempuan } \\
\text { maupun calon janin yang dikandung. }\end{array}$ \\
$\begin{array}{l}\text { Sukete jembrung, wayahe njabuti. } \\
\text { Rumputnya tinggi, waktunya mencabuti. }\end{array}$ & \\
Cak, lampune jek abang. & \\
Mas, lampunya masih merah. & \\
\hline
\end{tabular}




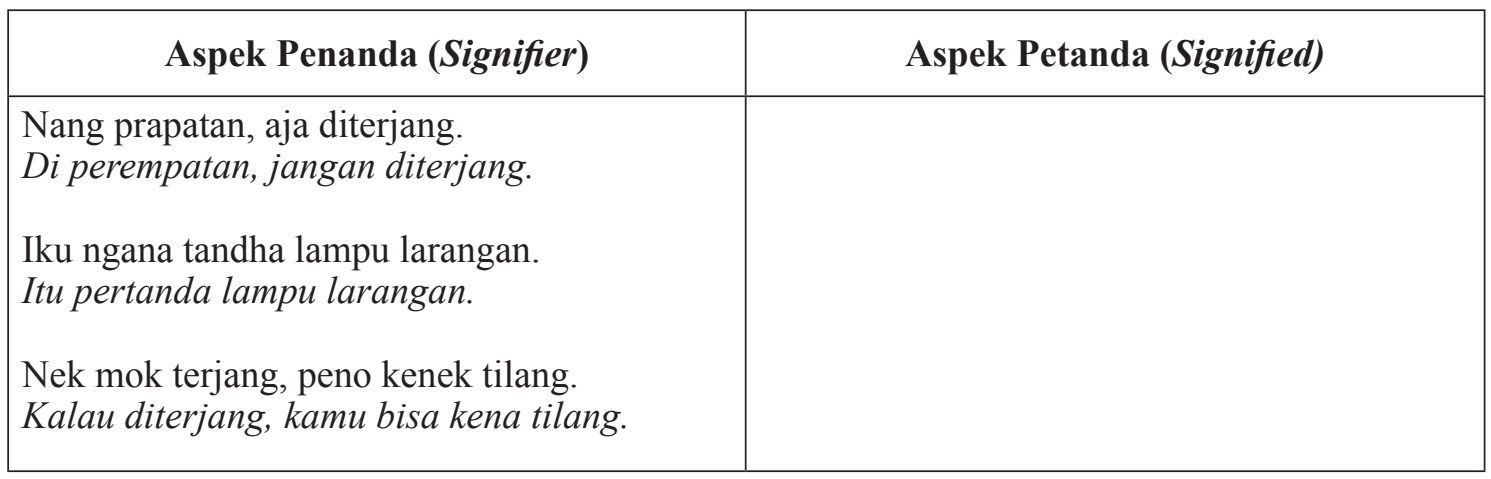

Memang sudah fitrahnya apabila seorang perempuan mengabdi secara penuh kepada sang suami. Akan tetapi, hal tersebut tidaklantas dimaknai secara mentah-mentah. Mengabdi secara penuh disini dapat diartikan bahwa segala sesuatu yang berdampak positif serta tidak merugikan keharmonisan hubungan rumah tangga. Salah satunya dalam hal pemenuhan kebutuhan seksual. Kebutuhan satu ini bisa dibilang mempunyai peranan penting dalam mewujudkan hubungan yang langgeng bagi pasangan suami istri. Meski, menjadi sesuatu yang lumrah dalam menjalin hubungan pernikahan, namun rasanya memang tak pantas apabila hal tersebut disampaikan dalam bentuk musik, apalagi campursari. Sebagai sebuah wujud kearifan lokal, harusnya campursari tetap dijaga "kemurnian" nilai-nilai kehidupan yang disampaikan melalui lirik-liriknya. Kearifan lokal diartikan sebagai kekayaan budaya lokal/setempat yang mengandung kebijakan hidup; pandangan hidup (way of life) yang mengakomodasi kebijakan (wisdom) dan kearifan hidup (Raharusun et al., 2016:7). Di lapangan, jelas bukan hanya kaum dewasa saja yang dapat mendengarkannya, generasi muda juga turut andil dalam menyerap nilai-nilai yang ada dalam lirik campursari tersebut. Memang menjadi keharusan jika muatan pendidikan moral harus tetap dikedepankan dalam musik campursari.

Tabel 5. Analisis bait ketiga lirik lagu Kebelet ciptaan Edy Sonata

\begin{tabular}{|c|c|}
\hline Aspek Penanda (Signifier) & Aspek Petanda (Signified) \\
\hline $\begin{array}{l}\text { Iki piye dadine. } \\
\text { Ini bagaimana jadinya. } \\
\text { Wis kadung kaya ngene. } \\
\text { Sudah terlanjur seperti ini. } \\
\text { Iki wis menthol nyengkal kaya jepite } \\
\text { sandhal. } \\
\text { Ini sudah membesar seperti jepitnya sandal } \\
\text { Wis ndhusel-ndhusel nang njero suwal. } \\
\text { Sudah desak-desakan di dalam celana. }\end{array}$ & $\begin{array}{l}\text { Sang suami pun merasabingung dengan } \\
\text { keadaan si istri yang sedang datang bulan. } \\
\text { Ia sudah sangat bergairah dan nafsunya } \\
\text { sungguh sudah memuncak. Ia merasa } \\
\text { benar-benar tak sanggup meredam } \\
\text { gejolak hasratnya tersebut. Sampai-sampai } \\
\text { alat kelamin si suami digambarkan sudah } \\
\text { amat "mendesak". Si istri juga merasa } \\
\text { jengkel dengan permintaan sang suami yang } \\
\text { tak tepat pada waktunya tersebut. }\end{array}$ \\
\hline
\end{tabular}




\begin{tabular}{|c|c|}
\hline Aspek Penanda (Signifier) & Aspek Petanda (Signified) \\
\hline $\begin{array}{l}\text { Kok kebacut tenan. } \\
\text { Kok, kebacut beneran. } \\
\text { Jek abang, kate mbok ganyang } \\
\text { Masih "merah" mau kamu ganyang. } \\
\text { Nek peno temen-temen, pancene ora tahan. } \\
\text { Kalau kamu benar-benar tidak tahan. } \\
\text { Paling gampang, cepitna lawang! } \\
\text { Paling mudah, jepitkan ke pintu! } \\
\text { Cak, aku ya wis eruh. } \\
\text { Mas, aku ya sudah tahu. } \\
\text { Sampeyan, ya kebelet ngunu. } \\
\text { Kamu, kebelet gituan. } \\
\text { Aku janji nek mari ora lali. } \\
\text { Aku janji nanti kalau sudah "selesai". } \\
\text { Ya entekna sing njemunuk iki. } \\
\text { Habiskanlah yang "besar" ini. }\end{array}$ & $\begin{array}{l}\text { Pada bait keempat ini, ia mengungkapkan } \\
\text { keheranannya kepada si suami, dalam } \\
\text { keadaan datang bulan masih saja meminta } \\
\text { dirinya untuk berhubungan suami istri. } \\
\text { Karena saking jengkelnya, melihat kelakuan } \\
\text { si suami yang tak tahan dengan nafsunya } \\
\text { tersebut, ia meminta kepada sang suami } \\
\text { untuk menjepitkan alat kelaminnya ke } \\
\text { pintu. Di bait terakhir, si istri memahami } \\
\text { sikap sang suami yang sedang nafsu untuk } \\
\text { melakukan hubungan seksual tersebut. } \\
\text { Sampai pada akhirnya, si istri berjanji } \\
\text { apabila nanti ia sudah selesai datang bulan, } \\
\text { ia siap melayani sang suami dengan sepuas- } \\
\text { puasnya. }\end{array}$ \\
\hline
\end{tabular}

Ranah pribadi, apalagi hubungan suami-istri, memang seyogyanya tidak menjadi konsumsi masyarakat secara umum. Apalagi kalau hal tersebut mengarah pada pemenuhan kebutuhan biologis (seksual). Bahasan tersebut amat sakral bila dikupas secara asal, tanpa memperhatikan siapa saja yang menjadi konsumen dari persebaran informasi tersebut. Media musik merupakan salah satu sarana yang dapat mempengaruhi masyarakat, sekaligus sarana komunikasi. Proses komunikasi dapat didekomposisi menjadi elemenelemen seperti sumber pesan, isi, media yang membawa pesan, penerima, dan umpan balik yang dihasilkan (Dewi, 2015:13). Komunikasi dilakukan melalui perantara bahasa. Maka dari itu, peran bahasa amat sentral. Maka dari itu, proses berkomunikasi diperlukan etika berbahasa yang baik serta benar. Etika berbahasa erat berkaitan dengan pemilihan kode bahasa, norma-norma sosial, dan sistem budaya yang berlaku dalam satu masyarakat (Chaer et.al., 2004:172). Etika berbahasa menjadi cerminan perilaku masyarakat pemakai bahasa tersebut.

Selain dua tema di atas, tema terakhir yang dikupas adalah masalah perceraian. Tema ini juga diangkat dalam bentuk lagu campursari. Fenomena sosial konflik rumah tangga yang berujung pada perceraian memang cukup sering terjadi di masyarakat. Lagu berjudul Aja Njaluk Pegat karya Rony Jembuk merupakan salah satu lagu yang membahas tema tersebut. Analisis 
lebih lanjut terkait lirik lagu campursari berjudul Aja Njaluk Pegat karya Rony Jembuk adalah sebagai berikut.

Tabel 6. Analisis bait pertama lirik lagu Aja Njaluk Pegat karya Rony Jembuk

\begin{tabular}{|c|c|}
\hline Aspek Penanda (Signifier) & Aspek Petanda (Signified) \\
\hline $\begin{array}{l}\text { Pancene bener omonge Tacik. } \\
\text { Memang benar kata Tacik. } \\
\text { Remuk kabeh dadi bojomu. } \\
\text { Remuk semua jadi istrimu. } \\
\text { Bendinane mbok keplaki. } \\
\text { Tiap hari kamu pukuli kepala. } \\
\text { Mbok gepuki, mbok pisuhi. } \\
\text { Kamu pukuli, kamu kasari } \\
\text { Sebab kakean cangkem. } \\
\text { Sebab, kebanyakan ngomel. } \\
\text { Dadi wong wedok. } \\
\text { Jadi perempuan. } \\
\text { Jok cerewet dik. } \\
\text { Jangan cerewet, dik. } \\
\text { Karo wong lanang. } \\
\text { Dengan lelaki. }\end{array}$ & $\begin{array}{l}\text { Lirik lagu Aja Njaluk Pegat, berkisah } \\
\text { dari suara hati seorang istri yang merasa } \\
\text { tersakiti. Sang suami selalu bersikap kasar } \\
\text { terhadap si istri. Memukul dan berbicara } \\
\text { kotor menjadi makanan wajib tiap hari bagi } \\
\text { sang istri. Rumah tangga benar-benar tak } \\
\text { berjalan harmonis. Sang suami menjawab } \\
\text { omelan dari si istri. Ia merasa risih dengan } \\
\text { keluhan dari si istri yang merasa tertekan } \\
\text { dengan perlakuan si suami. Ia meminta } \\
\text { kepada si istri untuk tidak cerewet dengan } \\
\text { laki-laki dan harus tunduk terhadap segala } \\
\text { perintahnya. }\end{array}$ \\
\hline \begin{tabular}{l}
\multicolumn{2}{c}{ Fenomena perceraian menjadi } \\
hal yang semakin sering terjadi di \\
masyarakat. Keutuhan keluarga \\
adakalnya mengalami perpecahan \\
berupa perceraian, sebagai akibat \\
hilangnya keserasian \\
mempertahankan keutuhan keluarga \\
(Waluya, 2007:41). Faktor retaknya \\
hubungan keluarga ini dapat terjadi \\
karena masalah ekonomi, pendidikan, \\
kesenjangan, maupun perselingkuhan. \\
Dari berbagai fakta yang ada, posisi
\end{tabular} & $\begin{array}{l}\text { perempuan seringkali diposisikan } \\
\text { di bawah laki-laki. Lebih parahnya } \\
\text { lagi, perempuan harus selalu tunduk } \\
\text { terhadap apapun tindakan dari } \\
\text { kaum adam. Kondisi seperti ini dapat } \\
\text { merusakan hubungan keluarga yang } \\
\text { telah terjalin. Keharmonisan harus } \\
\text { dibentuk dengan baik pada masing- } \\
\text { masing keluarga. Menurut Simanjuntak } \\
\text { (2013), keluarga yang kokoh harus } \\
\text { didirikan di atas pilar nilai yang juga } \\
\text { kokoh. }\end{array}$ \\
\hline
\end{tabular}
perempuan seringkali memang berada di bawah kaum laki-laki. Akibatnya, 
Tabel 7. Analisis bait kedua lirik lagu Aja Njaluk Pegat karya Rony Jembuk

\begin{tabular}{|c|c|}
\hline Aspek Penanda (Signifier) & Aspek Petanda (Signified) \\
\hline $\begin{array}{l}\text { Yo mesti wae. } \\
\text { Ya pasti saja. } \\
\text { Ora mbok ingoni. } \\
\text { Enggak dinafkahi. } \\
\text { Ora mbok openi. } \\
\text { Enggak dirawat. } \\
\text { Wani rabi mas. } \\
\text { Berani nikah mas. } \\
\text { Kudu tanggung jawab. } \\
\text { Harus tanggung jawab. } \\
\text { Yen jek seneng kelon mas } \\
\text { Kalo masih suka tidur berdua, mas. } \\
\text { Aja mara tangan. } \\
\text { Jangan mudah melayangkan tangan. } \\
\text { Melarat tak belani. } \\
\text { Melarat masih aku pahami. } \\
\text { Mbambunga tak openi. } \\
\text { Menggelandang pun aku rawat. } \\
\text { Apa ngene dibuka } \\
\text { Apa ini semua aku buka. } \\
\text { Kelonan nomer siji. } \\
\text { Tidur sambil berpelukan nomor satu } \\
\text { Mergawe nomor pitu. } \\
\text { Kerja nomor tujuh. } \\
\text { Mangan watu. } \\
\text { Makan batu. }\end{array}$ & $\begin{array}{l}\text { Di bait ketiga, sang istri membela diri } \\
\text { terhadap olokan si suami. Ia merasa tak } \\
\text { bersalah dengan sikap omelannya tersebut. } \\
\text { Ini beralasan karena ia tidak dinafkahi dan } \\
\text { tidak dirawat, tetapi berani menikahinya. } \\
\mathrm{Si} \text { istri menuntut sang suami untuk } \\
\text { bertanggung jawab dengan menafkahi } \\
\text { lahir maupun batinnya. Selain itu, si istri } \\
\text { juga mengatakan, kalau masih suka tidur } \\
\text { bersama jangan suka ringan tangan (mudah } \\
\text { melakukan kekerasan) terhadap si istri. } \\
\text { Meski dalam keadaan serba kekurangan } \\
\text { karena si suami yang kurang tanggung jawab } \\
\text { dalam menafkahi lahir dan batin, tetapi } \\
\text { sang istri tetap memahami. Tidak sampai } \\
\text { disitu, dalam keadaan menggelandang } \\
\text { pun si istri tetap menerima keadaan } \\
\text { tersebut apa adanya. Namun, karena sudah } \\
\text { parahnya sikap dari si suami, sang istri } \\
\text { mengancam untuk membuka aib yang ada } \\
\text { pada suaminya. Tindakan tersebut karena } \\
\text { sang suami hanya minta maunya saja, tetapi } \\
\text { malas bekerja untuk memenuhi nafkah } \\
\text { keluarga. }\end{array}$ \\
\hline $\begin{array}{l}\text { Perlakuan yang tidak seimbang } \\
\text { ini tampak pula dalam bahasa yang } \\
\text { notabene memang merupakan bagian } \\
\text { integral dari budaya (Dardjowidjojo, } \\
\text { 2003:141). Alhasil, sampai saat ini } \\
\text { anggapan bahwa perempuan harus } \\
\text { selalu 'dibawah' laki-laki masih begitu }\end{array}$ & $\begin{array}{l}\text { menjadi objek "ketertindasan" } \\
\text { tersebut. Perempuan acapkali memang } \\
\text { menjadi objek ketertindasan dengan } \\
\text { mengatasnamakan "kodrat"lahiriahnya. } \\
\text { Hal ini amat berkontradiksi dengan } \\
\text { upaya berbagai pihak dalam upaya } \\
\text { mengangkat isu feminisme di hadapan } \\
\text { masyarakat luas. }\end{array}$ \\
\hline
\end{tabular}

Akibatnya, perempuan masih selalu 
Tabel 8. Analisis bait ketiga lirik lagu Aja Njaluk Pegat karya Rony Jembuk

\begin{tabular}{|c|c|}
\hline Aspek Penanda (Signifier) & Aspek Petanda (Signified) \\
\hline $\begin{array}{l}\text { Nganggur taun-taunan. } \\
\text { Menganggur tahun-tahunan. } \\
\text { Mangan gak melok adang. } \\
\text { Makan gak ikut masak. } \\
\text { Cek nggantenge raimu. } \\
\text { Kok ganteng wajahmu. } \\
\text { Aku wis ora kuwat. } \\
\text { Aku sudah tak tahan. } \\
\text { Cepet golekna surat. } \\
\text { Cepat carikan surat. } \\
\text { Ndang dipegat. } \\
\text { Cepat dicerai. } \\
\text { Aja nekat dik } \\
\text { Jangan nekat, dik. } \\
\text { Aja aja njaluk dipegat. } \\
\text { Jangan, jangan minta cerai. } \\
\text { Sebab pegatan saiki surate larang. } \\
\text { Sebab cerai sekarang biaya suratnya mahal. }\end{array}$ & $\begin{array}{l}\text { Sikap kesal si istri semakin memuncak, } \\
\text { si suami hanya menganggur dan juga tidak } \\
\text { pernah ikut memasak (memberi belanja } \\
\text { ke istri). Kekesalan sang istri telah pada } \\
\text { puncaknya, ia merasa tidak tahan dan } \\
\text { akhirnya meminta kepada sang suami } \\
\text { untuk diceraikan. Puncak sikap dari sang } \\
\text { istri merupakan ekspresi ketidaktahanan ia } \\
\text { menghadapi sikap suami yang tidak pernah } \\
\text { peduli dengan nafkah untuk keluarga. } \\
\text { Diakhir bait lirik lagu ini, si pencipta } \\
\text { menggambarkan si suami yang melarang } \\
\text { istrinya untuk meminta cerai. Alasan si } \\
\text { suami karena surat permintaan cerai saat } \\
\text { ini mahal harganya. Selain itu, ketidakrelaan } \\
\text { sang suami juga menjadi penyebab ia } \\
\text { melarang sang istri untuk mengajukan } \\
\text { perceraian. }\end{array}$ \\
\hline
\end{tabular}

Perempuan menjadi objek ketidakadilan memang fenomena benang kusut yang tak mudah untuk diurai. Ketidakadilan gender disebabkan oleh ideologi, struktur, dan sistem sosial budaya yang menghendaki adanya streotipe gender yang membedakan ruang dan peran keduanya dalam berbagai bidang kehidupan (Rokhmansyah, 2016:18). Di satu sisi, perempuan dengan kemampuannya berupaya untuk mandiri serta tak sosok yang tangguh dalam menghadapi arus kehidupan. Akan tetapi, di sisi lain, perempuan juga tetap mawas diri dengan kodrat lahiriyahnya, yaitu sebagai pengurus rumah tangga (suami serta anak). Posisi inilah yang seringkali menjadi sumber munculnya sikap otoriter yang berbalut kekejaman dari pihak suami. Perempuan tetap punya hak untuk mengatur kehidupan, bukan berarti sikap ini menjadi alasan bagi para perempuan untuk membangkang terhadap petuah sang suami. Sinergitas diantara keduanya memang amat penting, guna terwujudnya sikap menghargai terhadap hak-hak perempuan (feminisme). Sehingga pada akhirnya, keutuhan keluarga 
dan masyarakat dapat tercipta, selaras dengan usaha peningkatan kesejahteraan perempuan dalam berbagai aspek kehidupan.

\section{Dampak Krisis Moral dalam Lirik Lagu Campursari}

Sebagai sebuah produk budaya, campursari memiliki misi penting bagi kelestarian kearifan lokal, utamanya pada kelompok masyarakat Jawa. Misi pemberdayaan kearifan lokal melalui media campursari memang memiliki strategi khusus, supaya fungsi hiburan serta pendidikan dapat meresap dengan baik kepada tiap penikmatnya. Melihat hal tersebut, memang sudah menjadi kewajiban apabila karya dalam bentuk musik campursari harus mengangkat tema-tema yang bermuatan moral didalamnya. Akan tetapi, seiring perkembangan zaman, tema-tema musik campursari yang beredar di masyarakat acapkali kurang mengakomodir misi mendidik masyarakat. Sematamata hanya mengedepankan aspek hiburan serta memenuhi permintaan pasar menjadi hal yang paling sering dijadikan alasan fenomena tersebut mulai marak belakangan ini. Padahal, tema yang kurang nilai moral tersebut amat berbahaya, utamanya bagi perkembangan pribadi generasi muda. Secara tidak langsung, mereka menjadi terbiasa mendengarkan isi musik campursari yang seharusnya hanya menjadi konsumsi kaum dewasa saja. Dampak yang bisa terjadi antara lain adalah (1) kaum muda menjadi terbiasa melakukan perbuatan tercela, (2) kaum muda yang tak siap menerima informasi kurang mendidik melalui isi lirik musik campursari tersebut akan mengalami fenomena "penasaran", dan (3) tindakan asusila semakin meningkat. Oleh karena itu, khusunya pencipta lagu campursari sedapat mungkin memperhatikan unsur hiburan serta pendidikan dalam setiap berkarya. Hal tersebut juga sejalan dengan upaya pemerintah dalam menumbuhkan pendidikan berkarakter.

\section{SIMPULAN}

Perkembangan teknologi ternyata tidak hanya mampu membawa ke arah kebaikan, tetapi dampak negatif yang muncul dari perkembangan tersebut juga cukup banyak. Salah satunya adalah kriris moral dalam lirik lagu campursari, terutama karya musisi Jawa Timur. Ada beberapa karya campursari musisi Jawa Timur yang mengangkat tema kurang mengandung unsur pendidikan. Tema tersebut antara lain adalah poligami, seksualitas, dan perceraian yang diwujudkan dalam bentuk karya musik campursari. Dalam penelitian ini, analisis lirik lagu campursari dengan tema yang kurang mendidik dilakukan dengan memergunakan pendekatan semiotika (Ferdinad D. Saussure). Aspek yang dicermati adalah unsur penanda (siginifier) pun petanda (signified) yang terdapat di dalam lirik lagu Bojo Ketelu karya Nur Bayan, Kebelet karya Edy Sonata, serta Aja Njaluk Pegat karya Rony Jembuk. Muatan pendidikan yang kurang dalam lirik lagu campursari tersebut dapat berpengaruh terhadap pribadi generasi muda antara lain (1) kaum muda menjadi terbiasa melakukan perbuatan tercela, (2) kaum muda yang tidak siap menerima 
informasi kurang mendidik melalui isi lirik musik campursari tersebut akan mengalami fenomena "penasaran", serta (3) tindakan asusila semakin meningkat.

Dengan semakin berkembangnya musik campursari pada masyarakat Jawa, khususnya di daerah Jawa Timur, hal ini diharapkan para musisi pencipta lagu campursari dapat mencipta karya yang mengantarkan nilai-nilai pendidikan karakter bagi masyarakat. Musik campursari dapat menjadi salah satu media untuk menyampaikan unsur pendidikan karakter bagi masyarakat. Ajaran moral dapat bermanfaat guna membangun sumber daya manusia yang berkualitas dan mampu berkontribusi bagi kemajuan bangsa di masa mendatang. Bukan hanya pihak pencipta, para penikmat lagu campursari juga harus pandai dalam menyaring isi dari lagu campursari yang dinikmati. Dengan terbentuknya sinergitas yang positif diantara seniman pencipta maupun para penikmat musik campursari, hal ini diharapkan campursari dapat menjadi salah media dalam mendidik masyarakat menjadi pribadi ynag berkarakter luhur.

\section{DAFTAR PUSTAKA}

Azizah, B. (2016). Degradasi moral bangsa indonesia. [Online]. URL http://www.kompasiana.com/ biyanka/degradasi-moral-bangsaindonesia_5742766d949773c304e Ob781. on May 10, 2017.

Abineno, J.L.Ch. (2002). Seksualitas dan pendidikan seksual. Jakarta: Gunung Mulia.

Chaer, A. (2003). Psikolinguistik (kajian teoritik). Jakarta: PT. Rineka Cipta.

Chaer, A., \& Agustina, L. (2004). Sosiolinguistik (perkenalan awal). Jakarta: PT. Rineka Cipta.

Dardjowidjojo, S. (2003). Rampai bahasa, pendidikan, dan budaya. Jakarta: Yayasan Obor Indonesia.

Dewi, I.C. (2015). Pengantar psikologi media. Jakarta: Prestasi Pustaka.

Hadiwardoyo, A.P. (1994). Moral dan masalahnya. Yogyakarta: Penerbit Kanisius.

Ibung, D.P. (2009). Mengembangkan nilai moral pada anak. Jakarta: Elex Media Komputindo.

Jamalus. (1988). Panduan pengajaran buku pengajaran musik melalui pengalaman musik. Jakarta: Proyek Pengembangan Lembaga Pendidikan Tenaga Kependidikan.

Kadarisman, A.E. (2008). Hipotesis Sapir-Whorf dan UngkapVerbal Keagamaan. Jurnal ilmiah masyarakat linguistik indonesia. Jakarta: Masyarakat Linguistik Indonesia dan Yayasan Obor Indonesia.

Krisnada. (2014). Pengertian dan fungsi musik campursari.[Online]. URL http://krisnadaf.blogspot. co.id/2014/09/campursari.html. on May 10, 2017. 
Moleong, L.J. (2005). Metofologi penelitian kualitatif. Bandung: Remaja Rosdakarya.

Mulia, M., et al. (2007). Poligami, siapa takut? (Perdebatan seputar poligami). Jakarta: Qultum Media.

Raharusun, A.M., et al. (2016). PAPPATAMMA: perlindungan perempuan dan anak berbasis kearifan lokal di indonesia. Yogyakarta: Deepublish.

Rokhmansyah, A. (2016). Pengantar gender dan feminisme. Yogyakarta: Garudhawaca.

Simanjuntak, B.A. (2013). Harmonious family (upaya membangun keluarga harmonis). Jakarta: Yayasan Pustaka Obor Indonesia.

Stevens, P.J.M., et al. (1992). Ilmu keperawatan (diterjemahkan oleh j.A tomasowa). Jakarta: Penerbit Buku Kedokteran.

Sudarsono. (1999). Metodologi penelitian: seni pertunjukan dan seni rupa (dengan contoh-contoh untuk tesis dan disertasi). Jakarta: Penerbit Masyarakat Seni Pertunjukan.

Sugiyono. (2016). Metode penelitian pendidikan (pendekatan kuantitatif, kualitatif, dan R\&D). Bandung: Alfabeta.

Suharsaputra, U. (2012). Metode penelitian kuantitatif, kulaitatif, dan tindakan. Bandung: PT. Refika Aditama.

Suprapto, T. (2009). Pengantar teori dan manajemen komunikasi. Yogyakarta: Media Pressindo.

Waluya, B. (2007). Sosiologi (menyelami fenomena sosial di masyarakat). Bandung: PT. Setia Purna Inves.

Widyarini, N. (2009). Seri psikologi populer: menuju perkawinan harmonis. Jakarta: Elex Media Komputindo. 